\title{
PRELIMINARY RESULTS REGARDING THE PRESENT MORPHOMETRIC CHARACTERS OF THERMAL RUDD, SCARDINIUS RACOVITZAI MÜLLER 1958 FROM PEȚEA SPRING NATURAL RESERVE
}

\author{
Gabriela GRIGORAŞ *, Tamás MÜLLER **, Adrian GAGIU ***, \\ Cecilia ŞERBAN *, **** and Ionuţ BONTAŞ *
}

* "Răsvan Angheluţă" Museum Complex of Natural Sciences, Aquarium Department, Regiment 11 Siret Street, 6A, RO-800340, Galați, Romania, griggabi@yahoo.com

** Szent István University, Institute of Environmental and Landscape Management, Department of Aquaculture, Pater K. Street 1, Gödöllő, H-2103, Hungary, muller.tamas@mkk.szie.hu

*** “Ţării Crişurilor” Museum, Natural Sciences Department, Dacia Boulevard 1-3, RO-410464, Oradea, Romania. stiintelenaturii@mtariicrisurilor.ro

**** "Dunărea de Jos" University, Faculty of Food Science and Environment, Domnească Street 111, RO-8002001 Galați, România, ceciliaserban@ugal.ro

DOI: 10.1515/trser-2015-0066

KEYWORDS: thermal rudd, Romania, endemic, shape, morphometry, variability.

\section{ABSTRACT}

The precarious temperature regime, associated with the negative influence of other environmental and biotic factors, represents a major risk for the survival of the thermal rudd from the lake Ochiul Mare, located in the Pârâul Pețea natural reserve. Therefore, a complex morphometric and body geometry analysis was conducted on specimens collected in 2013 in order to define the variability of the present population. The relatively small sample size is due to legislative restrictions on collecting endangered species, so statistical methods of analysis were applied to increase confidence in the assertions.

RÉSUMÉ: Les résultats préliminaires concernant la caractérisation morphométrique actuelle du rotengle thermale, Scardinius racovitzai Müller, 1958 de la Réserve Naturelle Pârâul Peţea.

Le régime précaire de température et en même temps l'influence négative des autres facteurs biotiques et de l'environnement est un risque majeur pour la survie et le potentiel reproductif du rotengle thermale, une espèce endémique de l'écosystème du lac thermal Ochiul Mare de la réserve naturelle Pârâul Peţea. C'est pourquoi l'analyse complexe de la morphométrie et la géométrie corporelle des spécimens capturés en 2013 a été effectuée pour caractériser la variabilité de la population courante. Les méthodes de traitement statistique ont été appliquées pour agrandir le degré de confiance des affirmations, en ce qui concerne les échantillons assez petits en raison des restrictions législatives pour la capture d'une espèce en péril.

REZUMAT: Rezultate preliminare privind caracterizarea morfometrică actuală a roşioarei termale, Scardinius racovitzai Müller 1958 din Rezervaţia Naturală Pârâul Peţea.

Regimul termic precar coroborat cu acţiunea negativă a altor factori de mediu şi biotici reprezintă un risc major pentru supravieţuirea şi potenţialul reproductiv al roşioarei termale Scardinius racovitzai, endemică în lacul termal Ochiul Mare din Rezervaţia Naturală Pârâul Peţea. De aceea, o analiză complexă din punct de vedere morfometric şi al geometriei corporale a specimenelor de roşioară termală, colectate în 2013 a fost realizată în vederea caracterizării variabilităţii populaţiei existente la momentul actual. Metode de prelucrare statistică au fost aplicate pentru a extinde gradul de confidenţă a afirmaţiilor, în condiţiile mărimii reduse a probelor impuse prin restricţiile legislative corespunzătoare gradului de periclitare a speciei. 


\section{INTRODUCTION}

This study is a part of a larger research effort regarding the ex situ conservation of two critically endangered animal species from the thermal lake in "Peţea Spring" Natural Reserve, near Oradea, north-western Romania.

Ochiul Mare Lake was formed in the second half of the Holocene (Sümegi et al., 2012 in Sîrbu et al., 2013) and is a unique ecosystem where endemic species are living; the lake is the only location in Europe where the Egyptian white water-lily (Nymphaea lotus L. var. thermalis) grows naturally, along with the thermal rudd Scardinius racovitzai (Müller, 1958) and the thermal snail Melanopsis parreyssii (Philippi, 1847) which are both critically endangered species (Freyhof and Kottelat, 2008; Fehér, 2013).

Water temperature is a limiting factor that affects fish development, reproduction and survival. Annual and multi-annual statistical sesonaly temperature measurements in recent years have revealed frequent values below $20^{\circ} \mathrm{C}$ during winter over significant surfaces of the thermal lake, a value previously considered the lowest tolerance limit (Bănărescu, 1964).

Telcean and Cupşa (2013) noted that the natural and ecological barriers between the "Ochiul Mare" thermal lake and related aquatic ecosystems have changed during the last few years, affecting fish population dynamics. Thermal conditions in "Ochiul Mare" lake have dramatically deteriorated as a result of overexploitation, consequently, there has been a drastic decrease of thermal spring flow, water temperature and level. The $42^{\circ} \mathrm{C}$ temperature according to Kováth (1977, in Telcean and Cupşa (2013) decreased in the '90s as shown in Crăciun (1997) in Telcean and Cupşa (2013), down to $34-35^{\circ} \mathrm{C}$ in summer and $26^{\circ} \mathrm{C}$ in winter. Our field measurements revealed water temperature values below references.

The drastic decrease of water level and temperature affected the entire ecosystem, so we proposed to test the morphological variability of the present thermal rudd population (Scardinius racovitzai) sampled during 2013, and compare it with a sample of its congener $S$. erythrophthalmus and to data from previous research (Müller, 1958; Bănărescu, 1964; Berinkey, 1960). There are several previous references regarding the morphology of this species; one considered this population as a species with a Miocene origin (Müller, 1958), another a subspecies with a more recent derivation from the Central European common rudd (Bănărescu, 2002). Telcean and Cupşa (2013) acknowledge the population as a valid species endemic in the thermal lake of the Peţea Creek. The present paper attempts to complete the data regarding the morphological features of the population that still persists in the thermal lake. Despite various references regarding the morphological, physiological and behavioural differences between the two species, application of molecular techniques are necessary for clarifying the taxonomic status of the thermal rudd population from the thermal lake (Bănărescu, 2002).

\section{MATERIAL AND METHODS}

A group of 19 thermal rudd specimens were approved for collection by Order no. 1231/2013 of the Environment and Climate Changes Ministry and were captured by use of scientific fishing net with 10-16 mm mesh sizes during sampling trips in August and October 2013.

The sampled fish were transported alive, in $50 \mathrm{l}$ plastic bags with a 1:3 water/oxygen ratio to the Aquarium facilities at the Museum Complex of Natural Sciences "Răsvan Angheluţă̌, Galaţi, Romania. 
Digital pictures were taken with a CANON A590 IS camera on the left side of each fish and 23 landmarks were defined and recorded as two-dimensional coordinates. Landmarks were selected to provide a homogeneous view of the whole shape. The operation was partially conducted on live specimens mindful of the project and legal demands (fish propagation and re-introduction of all adults and juveniles obtained by captive propagation back to their native environment).

A total of 14 morphometric characteristics of the fish were measured and the body weight of each individual was assessed to an accuracy of $0.1 \mathrm{~g}$. A multivariate approach was applied for the morphometric method using Systat 10.2.

Geometric methods were also applied with MorfoJ 1.05f. The shape information was extracted by Procrustes superimposition, which removes variation in size, position and orientation from data on landmark coordinates. The coordinates of the superimposed landmarks were used in multivariate statistical analysis to address the main question: the current variability of the thermal rudd population strongly affected by ecosystem deterioration. There is a degree of similarity between this species and its congener Scardinius erythrophtalmus and the statistical approach helps to analyse the separation between specific groups (species/ecotypes).

\section{RESULTS AND DISCUSSION}

"Pârâul Pețea" Natural Reserve. The morphometric data were studied in order to assess the variability of the present critically endangered population. The main body measurements were made on 19 thermal rudd individuals (Fig. 1).

The standard body length of $S$. racovitzai individuals is between $83.34-108.89 \mathrm{~mm}$ (minimum - maximum values), individual weight is 9.99-20.27 g.

Equation 1 allows the computing of the Fulton Factor by using the weight/length relationship, one estimated the condition status of fish.

$$
\text { (1) } \quad W=0.0038 * L^{3.7688}, R^{2}=0.8408
$$

The allometric coefficient $b$ assessed before spawning season that is 3.7688 reveals a positive allometric growth, with a high level of weight/length relationship ( $\mathrm{R}^{2}$ coefficient, of weight/length regression, was 0.84 ).

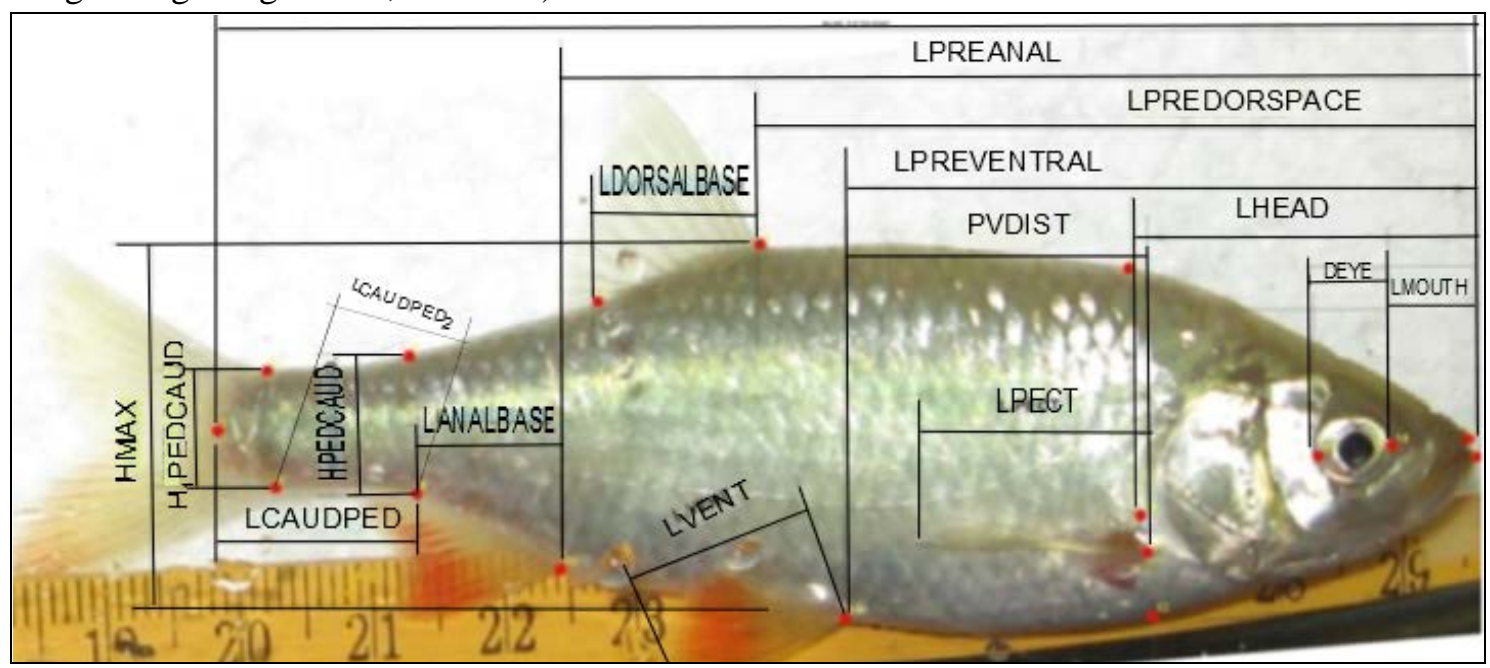

Figure 1: Determination of morphometric data of thermal rudd individuals sampled in 2013; explanations of morphometric characters are in table 1. 
The data obtained through body measurements of thermal rudd are listed in table 1 (confidence intervals with $95 \%$ confidence level, $\mathrm{n}=19$ individuals). The values were expressed as percentage from standard length, with the exception of $\mathrm{LMOUTH}_{2}$ (length of mouth as percentage from head length), $\mathrm{DEYE}_{2}$ (eye diameter as percentage from head length), HPEDCAUD (maximum height of caudal peduncle as percentage from caudal peduncle length), LPECT $_{2}$ (length of pectoral fin as percentage of the distance between pectoral and ventral fins insertions).

The resulting data was compared to data published by Müller (1959), Bănărescu (1964), based on 69 individuals, and Berinkey (1960), based on five individuals, and data obtained by Kottelat and Freyhof (2007).

Table 1: Statistical parameters of the main morphological features of the thermal rudd (confidence intervals, $\mathrm{P}<0.05)$. We noted the references of Kottelat and Freyhof (2007). The differences from references are bolded.

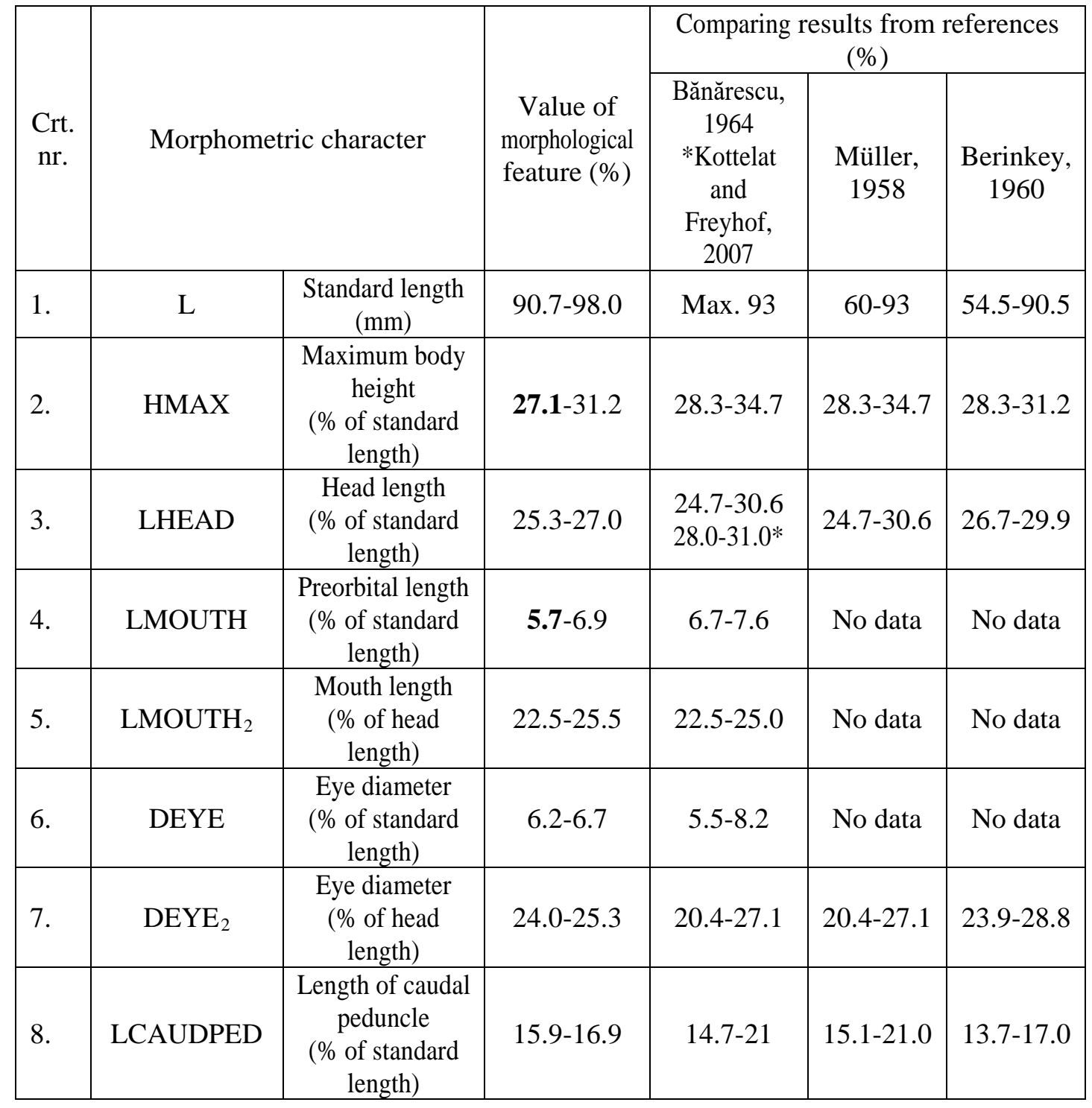




\begin{tabular}{|c|c|c|c|c|c|c|}
\hline 9. & LCAUDPED $_{2}$ & \begin{tabular}{|c|} 
Length of caudal \\
peduncle \\
(\% of standard \\
length)
\end{tabular} & 8.9-15.5 & No data & No data & No data \\
\hline 10. & $\begin{array}{c}\mathrm{H}_{1} \text { PEDCAU } \\
\mathrm{D}\end{array}$ & $\begin{array}{c}\text { Minimum height } \\
\text { of caudal } \\
\text { peduncle } \\
\text { (\% of standard } \\
\text { length) } \\
\end{array}$ & 9.7-10.1 & $10.3-11.3$ & No data & $10.9-14.5$ \\
\hline \multirow{2}{*}{11.} & \multirow{2}{*}{ HPEDCAUD } & $\begin{array}{l}\text { Maximum } \\
\text { height of caudal } \\
\text { peduncle } \\
\text { (\% of caudal } \\
\text { peduncle length) }\end{array}$ & $0.7-\mathbf{0 . 8}$ & No data & No data & No data \\
\hline & & $\begin{array}{l}\text { Maximum } \\
\text { height of caudal } \\
\text { peduncle } \\
(\% \text { of } \\
\left.\text { LCAUDPED }_{2}\right) \\
\end{array}$ & $1.0-1.3$ & $1.3-1.7^{*}$ & No data & No data \\
\hline 12. & $\begin{array}{c}\text { LPREDORSPA } \\
\text { CE }\end{array}$ & $\begin{array}{c}\text { Predorsal } \\
\text { distance } \\
\text { (\% of standard } \\
\text { length) } \\
\end{array}$ & 57.3-59.0 & $57-62$ & No data & No data \\
\hline 13. & LPECT & $\begin{array}{c}\text { Pectoral fin } \\
\text { length } \\
\text { (\% of standard } \\
\text { length) } \\
\end{array}$ & 17.0-19.3 & $18.5-21.3$ & No data & No data \\
\hline 14. & $\mathrm{LPECT}_{2}$ & $\begin{array}{l}\text { Pectoral fin } \\
\text { length } \\
\text { (\% of the } \\
\text { distance } \\
\text { between } \\
\text { pectoral and } \\
\text { ventral fins) }\end{array}$ & 67.9-76.2 & $60.2-69.3$ & $60.2-69.3$ & 71.1-89.8 \\
\hline 15. & LVENT & $\begin{array}{c}\text { Ventral fin } \\
\text { length } \\
\text { (\% of standard } \\
\text { length) } \\
\end{array}$ & 13.9-15.5 & $15.4-18$ & No data & No data \\
\hline 16. & LPREANAL & $\begin{array}{c}\text { Pre-anal } \\
\text { distance } \\
\text { (\% of standard } \\
\text { length) }\end{array}$ & 71.9-73.1 & $70-76$ & No data & 75.6-78.5 \\
\hline 17. & $\begin{array}{c}\text { LPREVENTR } \\
\text { AL }\end{array}$ & $\begin{array}{l}\text { Pre-ventral } \\
\text { distance } \\
\text { (\% of standard } \\
\text { length) }\end{array}$ & $48.3-50.8$ & $50-66$ & No data & $52.6-55.3$ \\
\hline
\end{tabular}




\begin{tabular}{|c|c|c|c|c|c|c|}
\hline 18. & $\begin{array}{c}\text { LDORSALBA } \\
\text { SE }\end{array}$ & $\begin{array}{c}\text { Length of dorsal } \\
\text { fin base } \\
\text { (\% of standard } \\
\text { length) }\end{array}$ & $11.4-12.5$ & $10.6-14$ & No data & No data \\
\hline 19. & $\begin{array}{c}\text { LANALBAS } \\
\mathrm{E}\end{array}$ & $\begin{array}{c}\text { Length of anal } \\
\text { fin base } \\
\text { (\% of standard } \\
\text { length) }\end{array}$ & $10.7-11.7$ & $10.5-12.7$ & No data & $10.9-14.5$ \\
\hline PVDIST & $\begin{array}{c}\text { Distance } \\
\text { between } \\
\text { pectoral and } \\
\text { ventral fins } \\
\text { insertions } \\
\text { (\% of standard } \\
\text { length) }\end{array}$ & $24.4-26.0$ & No data & No data & No data \\
\hline
\end{tabular}

It was observed that the lowering of ranges of some morphometric characteristics can be linked to the phenotypic plasticity of the fish which quickly adapt by modifying their physiology and behaviour to environmental changes (Bohlen et al., 2008). The dwarfism as a response to the thermal environment is noted by Bohlen et al., (2008) and shows the comparably small size in Cobitis elongatoides and Sabanejewia balcanica under the influence of warm water from the Băile Episcopeşti thermal spring.

The modification tendency of some of the morphological features of thermal rudd is consistent with the opinion expressed by Bănărescu (2002) regarding the recent derivation of species from the Central European common rudd, Scardinius erythrophthalmus.

The morphological variation in fish from the $S$. racovitzai sample was compared with data published by different authors (Müller, 1958; Berinkey, 1960; Bănărescu, 1964; Kottelat and Freyhof, 2007) and includes differences in magnitude to its congener, $S$. erythrophthalmus, and is assessed by the hierarchical clustering complete linkage method (Wilkinson, 2005). This procedure allows detection of natural groupings in data (Wilkinson, 2005). The data matrix used includes five morphological characteristics: body height, the lengths of head and caudal peduncle, minimum caudal peduncle height and eye diameter that can be found in all the next five cases:

- studies of Bănărescu (1964) and Berinkey (1960) regarding S. racovitzai (the results obtained by Müller, 1958 are similar to those published by Bănărescu, 1964);

- study of Bănărescu (1964) regarding S. erythrophthalmus;

- the results from this study regarding the morphological features in thermal rudd;

- for a better representation of data grouping, we added the measurements of these five characters in S. erythrophthalmus captured and measured within this research.

The output of hierarchical clustering is displayed in the dendrogram from figure 2 that represents the evidence of similarity and dissimilarity between results. The morphometric dendrogram revealed the clustering of our results and those obtained by the authors mentioned above, regarding the $S$. racovitzai morphometry. 


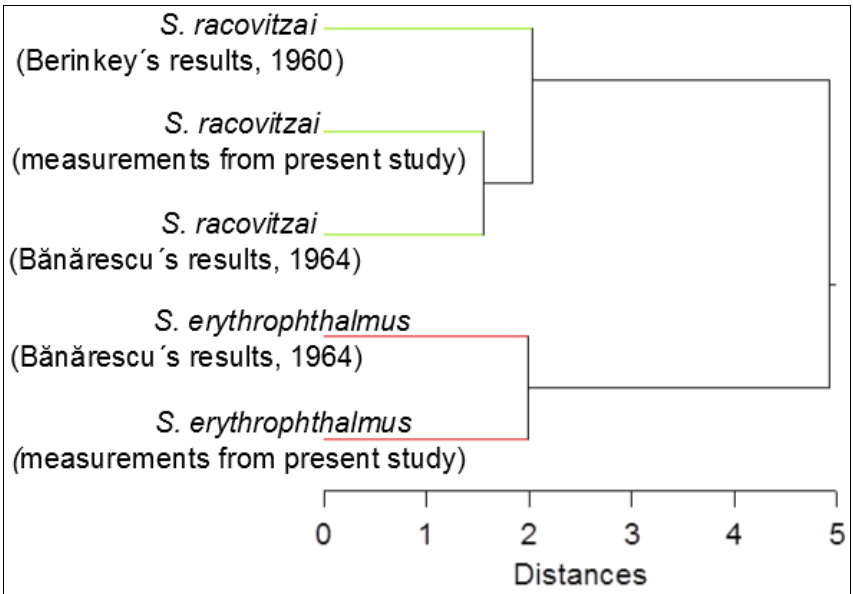

Figure 2: Hierachical clustering analysis based on morphometric data.

The algorithm used was the complete linkage clustering (nearest neighbour) with the Euclidean distance as a similarity measure.

The distances between similar clusters and the remoteness from S. erythrophthalmus clusters is shown in table 2 . The clusters containing the body measurements in S. racovitzai from different studies (the results from this research as well as those mentioned by Bănărescu, 1964 and Berinkey, 1960) were joined at the smallest Euclidean distances: 1.561 and 2.035.

Table 2: Euclidean distances between clusters.

\begin{tabular}{|l|l|c|c|}
\hline Cluster containing: & and Cluster containing: & $\begin{array}{c}\text { Were } \\
\text { joined } \\
\text { at } \\
\text { distance }\end{array}$ & $\begin{array}{c}\text { No. of } \\
\text { members } \\
\text { in new } \\
\text { cluster }\end{array}$ \\
\hline $\begin{array}{l}\text { S. racovitzai } \\
\text { (Bănărescu, 1964 results) }\end{array}$ & $\begin{array}{l}\text { S. racovitzai } \\
\text { (measurements from this study) }\end{array}$ & 1.561 & 2 \\
\hline $\begin{array}{l}\text { S. } \text { erythrophthalmus } \\
\text { (measurements from this study) }\end{array}$ & $\begin{array}{l}\text { S. } \text { erythrophthalmus } \\
\text { (Bănărescu, 1964 results) }\end{array}$ & 1.994 & 2 \\
\hline $\begin{array}{l}\text { S. racovitzai } \\
\text { (Berinkey, 1960 results) }\end{array}$ & $\begin{array}{l}\text { S. racovitzai } \\
\text { (Bănărescu, 1964 results) }\end{array}$ & 2.035 & 3 \\
\hline $\begin{array}{l}\text { S. } \text { erythrophthalmus } \\
\text { (measurements from this study) }\end{array}$ & $\begin{array}{l}\text { S. racovitzai } \\
\text { (Berinkey, 1960 results) }\end{array}$ & 4.919 & 5 \\
\hline
\end{tabular}

Statistical analysis of morphometric data carried out during experiments. Principal component analysis allowed the identification of a combination of variables that influence the overall variability and the size of their impact (Prein et al., 1993; Stenson and Wilkinson, 2005). This approach to data analysis was applied in order to expand the degree of confidence in the conclusions, taking into account the small sample size which was limited by legal permit (1231 Order from 2013 of MMSC regarding the approval of exemption for scientific purposes capturing in some wildlife species). 
The principal components analysis of morphometric values prove that the first two principal components sum up to $57.454 \%$ of the total variance $(42.326 \%$ for PC1 and $15.128 \%$ for PC2), which means that more than $57 \%$ of the variance of all body variables is explained by the first two factors (Fig. 4). Looking for variables with high loadings, it is observed that the PC1 includes the significant, positive contribution of body height, caudal peduncle height and length, ventral, anal and dorsal fins length, and negative contribution of head length, mouth length, preanal, predorsal, preventral and preorbital distances (Fig. 4a). In the same way, PC2 indicates the positive contribution of characteristics like fin lengths (ventral and pectoral fins) (Fig. 4b).

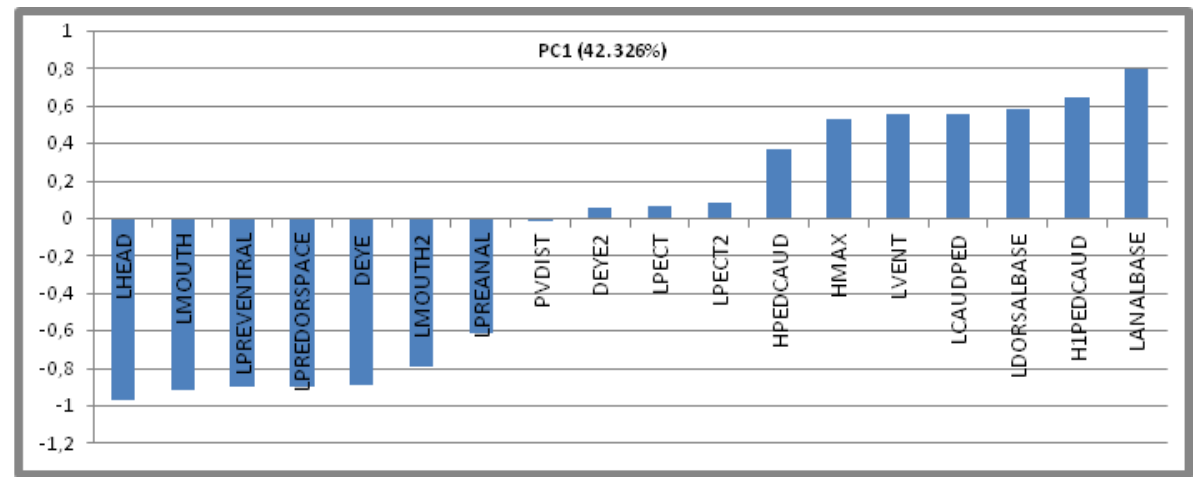

Figure 4a: Variables loaded in the principal component analysis (PCA) of morphometric measurement values of Scardinius racovitzai $(\mathrm{n}=12)$. The full names of variables (Tab. 1$)$.

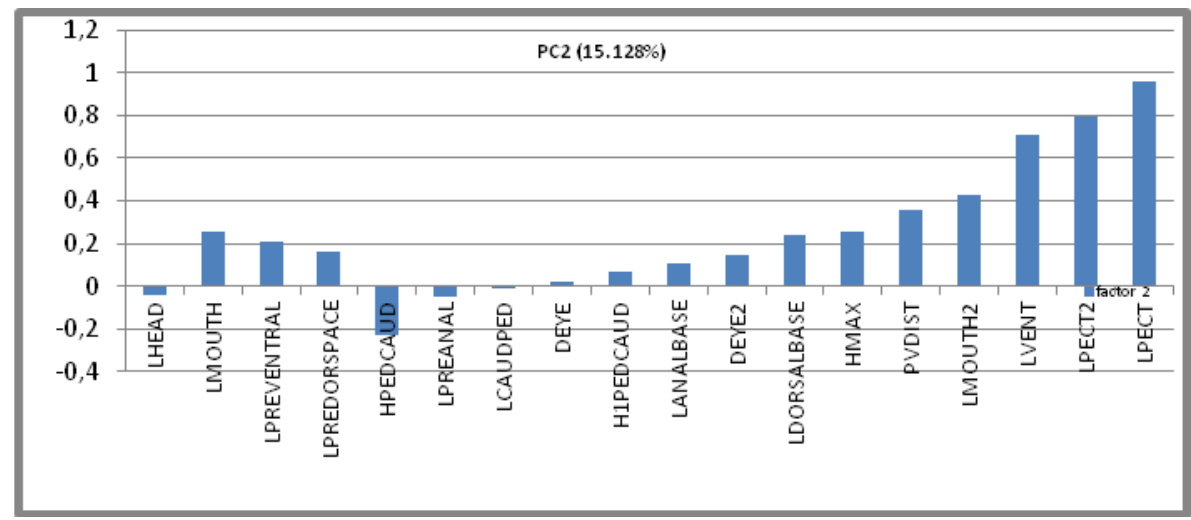

Figure 4b: Variables loaded in the principal component analysis (PCA) of morphometric measurement values of Scardinius racovitzai $(n=12)$. The full names of variables (Tab. 1$)$.

Morphometric comparison between S. racovitzai and S. erythrophthalmus. A multivariate test was applied for a comparison between the thermal rudd sample captured in 2013 and a sample of its congener S. erythrophthalmus (eight individuals) collected from the Danube River population (Mm 80) in order to complete the data regarding the morphological variation in thermal rudd and to assess its plasticity.

The significant differences in the main characters of fish from the two samples by applying the T test $(\mathrm{P}<0.05)$ were noted in table 3 as "characteristic $S$ ". 
Table 3: Mean values of variables (\%).

\begin{tabular}{|c|c|c|}
\hline Morphometric feature & $\begin{array}{l}\text { Non-thermal rudd } \\
\text { (Scardinius } \\
\text { erythrophthalmus) }\end{array}$ & $\begin{array}{c}\text { Thermal } \\
\text { rudd }\end{array}$ \\
\hline HMAX $^{S}$ & 34.5 & 29.1 \\
\hline LHEAD $^{\text {S }}$ & 19.5 & 26.1 \\
\hline LMOUTH $^{\text {S }}$ & 3.8 & 6.3 \\
\hline $\mathrm{LMOUTH}_{2}{ }^{\mathrm{S}}$ & 19.6 & 24.0 \\
\hline $\mathrm{DEYE}^{\mathrm{S}}$ & 4.8 & 6.5 \\
\hline $\mathrm{DEYE}_{2}$ & 24.4 & 24.7 \\
\hline LCAUDPED $^{\mathrm{S}}$ & 17.8 & 16.4 \\
\hline H1PEDCAUD $^{S}$ & 10.5 & 9.9 \\
\hline HPEDCAUD $^{S}$ & 0.8 & 0.8 \\
\hline LPREDORSPACE $^{\mathrm{S}}$ & 54.3 & 58.1 \\
\hline LPECT & 19.2 & 18.2 \\
\hline$\overline{\mathrm{LPECT}}_{2}$ & 75.1 & 72.0 \\
\hline LVENT $^{\mathrm{S}}$ & 17.8 & 14.7 \\
\hline LPREANAL & 67.2 & 72.5 \\
\hline LPREVENTRAL $^{\mathrm{S}}$ & 44.5 & 49.6 \\
\hline LDORSALBASE $^{\mathrm{S}}$ & 13.1 & 12.0 \\
\hline LANALBASE $^{S}$ & 13.4 & 11.2 \\
\hline PVDIST $^{\mathrm{S}}$ & 25.8 & 25.2 \\
\hline
\end{tabular}

The objective discriminant analysis (developed by Fisher, 1936, and quoted by Engelman, 2005) of morphometric measurements on samples from the two species was the identification/verification of the most relevant characteristics for discerning between two samples of the two species (Engelman, 2005). The sample frequencies are noted on table 4. The thermal rudd group is divided in three subsamples in relation with the time of capture (August, October and November 2013).

Table 4: Group frequencies used for discriminant analysis.

\begin{tabular}{|l|c|c|c|c|}
\hline Sample & S. racovizai (1) & S. racovizai (2) & S. racovizai (3) & S.erythrophthalmus (4) \\
\hline $\begin{array}{l}\text { Number of } \\
\text { individuals/sample }\end{array}$ & 5 & 7 & 7 & 8 \\
\hline
\end{tabular}

Between groups F-matrix shows the $\mathrm{F}$ parameter value for testing the differences between each pair of groups and all the variables. The $\mathrm{F}$ values are proportional to distances measured on morphospace. They are computed from Mahalanobis statistics (developed by the Indian statistician Prasanta C. Mahalanobis) (Engelman, 2005) and prove the correct classification of the thermal rudd groups with the farthest distance from the S. erythropthalmus group (5.736, 10.570 and 6.412 respectively) (Tab. 5).

The reliability of discriminant analysis of morphometric characters of fish from the two species is assessed by Wilks' lambda statistical index, which tests the dispersion among all the groups on all the variables (Engelman, 2005).

The computed value of Wilks' lambda statistical parameter (Wilks' lambda $=0.0152$, prob $=0.0000)$ reveal discrimination with an advanced degree of confidence $(\mathrm{P}<0.05)$. 
The F-to-remove statistics (Engelman, 2005) determine the relative importance of variables/morphometric characters included in the model (Tab. 6). We noted that a number of six morphological characteristics are the most useful for discriminating between the species (head features, caudal peduncle, pectoral and ventral fins lengths).

Table 5: Between groups F-matrix and distances between Scardinius racovitzai groups (August, October and November samples) and S. erythrophthalmus group (June sample) ( $\mathrm{df}=17$ and seven respectively).

\begin{tabular}{|l|c|c|c|c|}
\hline Fish sample & $\begin{array}{c}\text { Thermal rudd, } \\
\text { 2013, August } \\
\text { sample (1) }\end{array}$ & $\begin{array}{c}\text { Thermal rudd, } \\
\text { 2013, October } \\
\text { sample (2) }\end{array}$ & $\begin{array}{c}\text { Thermal rudd, } \\
\text { 2013, } \\
\text { November } \\
\text { sample (3) }\end{array}$ & $\begin{array}{c}\text { Non-thermal } \\
\text { rudd } \\
\text { (S. erythropht.), } \\
\text { 2014, June } \\
\text { sample (4) }\end{array}$ \\
\hline Thermal rudd, 2013, August sample (1) & 0.000 & & & \\
\hline Thermal rudd, 2013, October sample (2) & 3.448 & 0.000 & 3.184 & $\mathbf{1 0 . 5 7 0}$ \\
\hline Thermal rudd, 2013, November (3) & 2.030 & & 0.000 & $\mathbf{6 . 4 1 2}$ \\
\hline $\begin{array}{l}\text { Non-thermal rudd } \\
\text { (S. erythropht.), 2014, June sample (4) }\end{array}$ & $\mathbf{5 . 7 3 6}$ & & & 0.000 \\
\hline
\end{tabular}

Table 6: F-to-remove statistics of main morphometric characters of two fish groups, Scardinius racovitzai and S. erythrophthalmus.

\begin{tabular}{|c|c|c|c|c|c|c|c|}
\hline \multicolumn{2}{|c|}{ Variable } & \multirow{2}{*}{$\begin{array}{l}\begin{array}{l}\text { F-to- } \\
\text { remove }\end{array} \\
3.17\end{array}$} & \multirow{2}{*}{$\begin{array}{c}\text { Tolerance } \\
0.20\end{array}$} & \multicolumn{2}{|c|}{ Variable } & \multirow{2}{*}{\begin{tabular}{|r|}
$\begin{array}{l}\text { F-to- } \\
\text { enter }\end{array}$ \\
2.90 \\
\end{tabular}} & \multirow{2}{*}{$\begin{array}{l}\text { Toleranc } \\
\text { e } \\
0.0011 \\
\end{array}$} \\
\hline 2 & HMAX & & & 19 & PVDIST & & \\
\hline 3 & LHEAD & \multicolumn{2}{|r|}{13.15} & \multicolumn{4}{|c|}{0.01} \\
\hline 4 & LMOUTH & \multicolumn{2}{|r|}{2.57} & \multicolumn{4}{|c|}{0.01} \\
\hline 5 & LMOUTH2 & \multicolumn{2}{|r|}{2.22} & \multicolumn{4}{|c|}{0.02} \\
\hline 6 & DEYE & \multicolumn{2}{|c|}{145.79} & \multicolumn{4}{|c|}{0.01} \\
\hline 7 & DEYE2 & \multicolumn{2}{|c|}{-10.31} & \multicolumn{4}{|c|}{0.02} \\
\hline 8 & LCAUDPED & \multicolumn{2}{|c|}{5.88} & \multicolumn{4}{|c|}{0.23} \\
\hline 9 & H1PEDCAUD & \multicolumn{2}{|r|}{1.91} & \multicolumn{4}{|c|}{0.28} \\
\hline 10 & HPEDCAUD & \multicolumn{2}{|r|}{2.21} & \multicolumn{4}{|c|}{0.20} \\
\hline 11 & LPREDORSPACE & \multicolumn{2}{|r|}{1.30} & \multicolumn{4}{|c|}{0.16} \\
\hline 12 & LPECT & \multicolumn{2}{|r|}{6.88} & \multicolumn{4}{|c|}{0.07} \\
\hline 13 & LPECT2 & \multicolumn{2}{|r|}{11.93} & \multicolumn{4}{|c|}{0.06} \\
\hline 14 & LVENT & \multicolumn{2}{|r|}{3.56} & \multicolumn{4}{|c|}{0.25} \\
\hline 15 & LPREANAL & \multicolumn{2}{|r|}{1.46} & \multicolumn{4}{|c|}{0.42} \\
\hline 16 & LPREVENTRAL & \multicolumn{2}{|r|}{-2.40} & \multicolumn{4}{|c|}{0.04} \\
\hline 17 & LDORSALBASE & \multicolumn{2}{|r|}{0.95} & \multicolumn{4}{|c|}{0.45} \\
\hline 18 & LANALBASE & & -2.38 & & & 0.22 & \\
\hline
\end{tabular}

The classification matrix shows a high percentage of classification validation in all cases (100\% correct classification). 
The correct classification in thermal rudd was also confirmed by Jackknife matrix analysis that uses functions from all data except the case being classified (Engelman, 2005) (Tab. 7); the lower percent in the Jackknife panel could be assigned to the high number of predictors and small size of $S$. erythrophthalmus group.

Table 7: Jackknifed classification matrix.

\begin{tabular}{|l|c|c|c|}
\hline Sample & $\begin{array}{c}\text { Thermal rudd } \\
\text { (S. racovitzai) }\end{array}$ & $\begin{array}{c}\text { Non-thermal rudd } \\
\text { (S. erythrophthalmus) }\end{array}$ & $\%$ correct \\
\hline Thermal rudd (Scardiunius racovitzai) & 19 & 0 & 100 \\
\hline Non-thermal rudd (Scardinius erythrophthalmus) & 3 & 5 & 63 \\
\hline Total & 22 & 5 & 89 \\
\hline
\end{tabular}

The Canonical scores plot generates the graphic in which the axes are canonical variables and the points are the canonical variables scores (Engelman, 2005). The confidence ellipse ( $\mathrm{P}<0.05$ ) of each group is centred on the centroid of each group (Fig. 5). Based on body measurement values, the groups are clearly distinct. The distance between the ellipses of groups from the same (thermal) ecosystem was explained by the different methods for taking pictures (live/dead specimen) and the small number of observations.

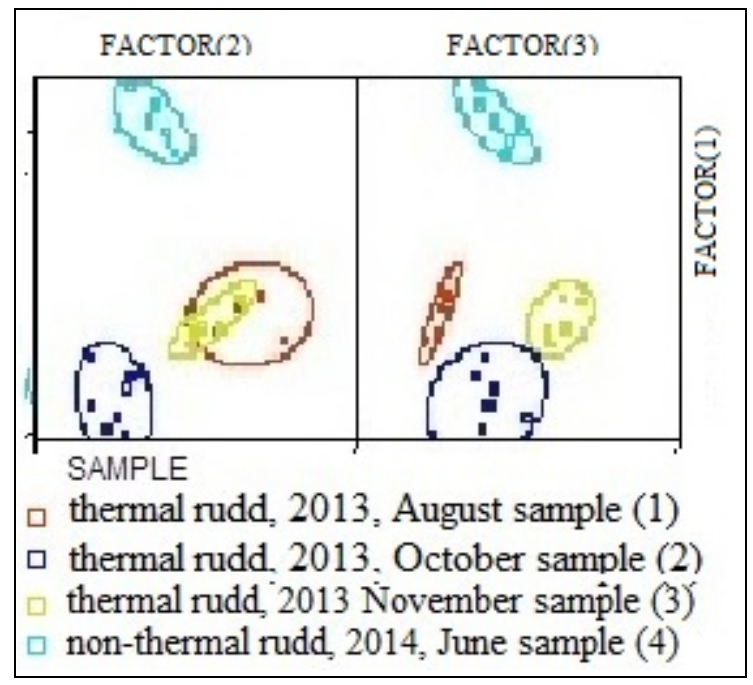

Figure 5: Diagram of canonical scores (95\% confidence level) of the four samples on which discriminant analysis was applied: Peţea stage 1-3 and Danube.

The geometric statistical analysis. The $S$. racovitzai was considered a subspecies for a long time by some authors (Bănărescu, 1964), although the same author, in 2004, still considered that molecular techniques were necessary in order to clarify the taxonomic status of thermal rudd. A second approach of analysing of differences between $S$. racovitzai and its congener, S. erythrophthalmus was made by the body shape analysis. The 19 thermal rudd individuals randomly chosen from the fish population were used for a comparative, intraspecific and interspecific study with closely related S. erythrophthalmus (eight individuals). 
The statistical test was made by use of the MorphoJ software through the analysis of the principal components analysis (PCA) (Klingenberg, 2011) and canonical variate analysis (CVA) (Klingenberg, 2011) of body shape.

The principal components analysis (PCA) allows for conclusions about shape variation between the samples, and was also used as an ordination analysis for examining the arrangement of specimens in morphospace and to discover patterns in the relations among observations (Klingenberg, 2011). The shape information was extracted by Procrustes superimposition (Goodall, 1991 quoted by Klingenberg, 2011) which removes variation in size, position and orientation from data on landmark coordinates (Polly, 2012; Zelditch et al., 2004 in Klingenberg, 2011). Each specimen is represented by the relative positions of morphological landmarks that can be located precisely and establish a one-to-one correspondence among all specimens included in the analysis (Klingeneberg, 2011). Information on the size of the landmark configuration is retained in the data set and available for subsequent analyses (Polly, 2012; Dryden and Mardia, 1998 in Klingenberg, 2011).

PCA was performed ing the co-variance matrix of the Procrustes coordinates of each sample and the first two components sum $62.494 \%$ of the total variance (Tab. 8).

The two scatter plots of PC scores from figures 6 and 7 display the patterns in the relations between observations, two ways of their grouping being applied for a higher confidence of results. PC1 separated the S. racovizai and S. erythrophthalmus (Fig. 6). Similarly, PC1 separated S. racovitzai individuals from 2013, August, October, November subsamples and S. erythrophthalmus (Fig. 7).

Table 8: Eigenvalues of each component expressed by unit of Procrustes variance (\% percent of total variance).

\begin{tabular}{|c|c|c|c|}
\hline Component & Eigenvalues & \% Variance & Cumulative \% \\
\hline 1 & 0.00109393 & 47.109 & 47.109 \\
\hline 2 & 0.00035726 & 15.385 & 62.494 \\
\hline 3 & 0.00018603 & 8.011 & 70.505 \\
\hline
\end{tabular}

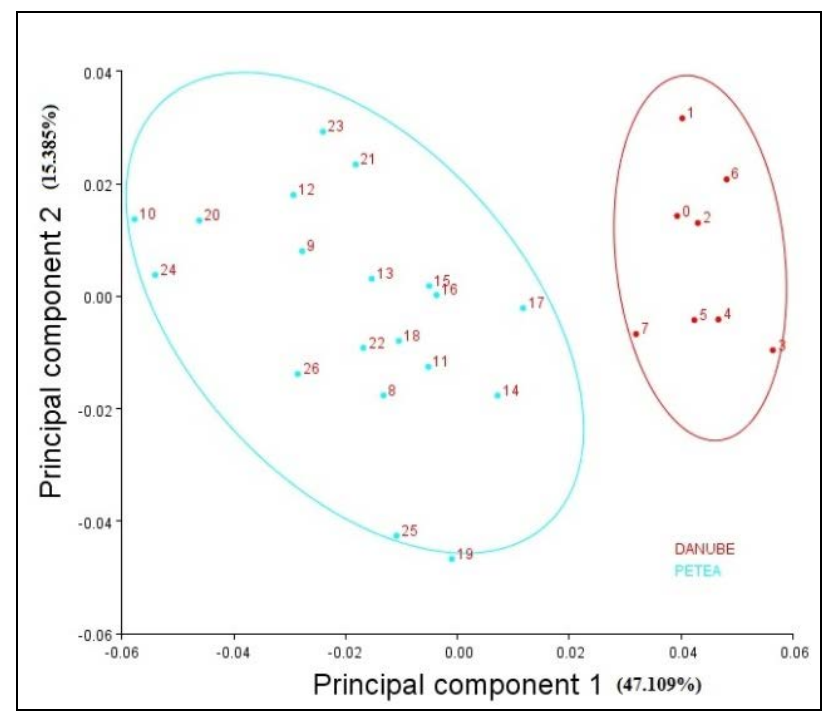

Figure 6: PC scores and the disposition of specimens in the morphospace of the multivariate analysis. Coordinates of PCA plot grouping by equal frequency confidence ellipses $(\mathrm{P}=0.9)$;

The specimens are grouped by species - S $_{\text {. racovitzai, }-}-{ }_{\text {S. erythrophthalmus. }}$ 


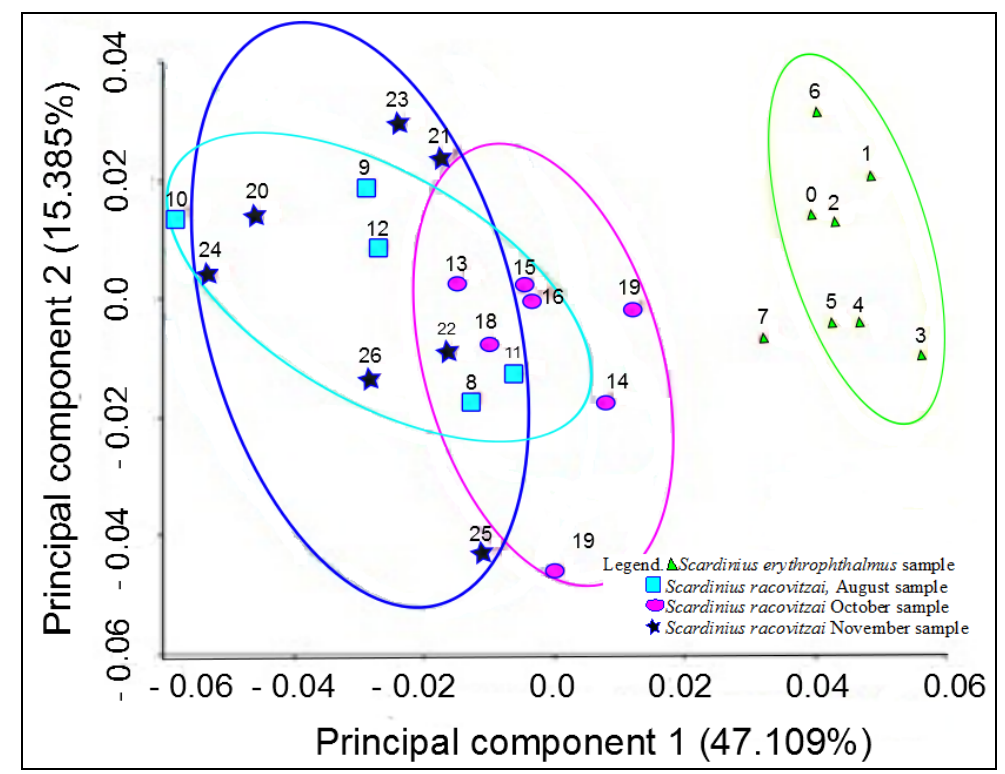

Figure 7: PC scores for the first two components and the disposition of specimens in the morphospace of the multivariate analysis (PC1 47.109\%, PC2 15.385\%). Coordinates of PCA plot grouping by equal frequency confidence ellipses $(\mathrm{P}=0.9)$; The specimens are grouped by sampling stage ( 1 - thermal rudd, 2013 August sample, 2 - thermal rudd, 2013 October sample, 3 - thermal rudd, 2013 November sample, 4 - Scardinius erythrophthalmus, 2014 June sample).

Canonical variate analysis (CVA) allows a different type of ordination analysis, which maximizes the separation of specified groups (species/ecotypes, Klingenberg, 2011). The results provided the shape features that best distinguish among the fish groups from Peţea Lake and Danube River.

The scatter plot of the CV scores displays the species separation (Fig. 8).

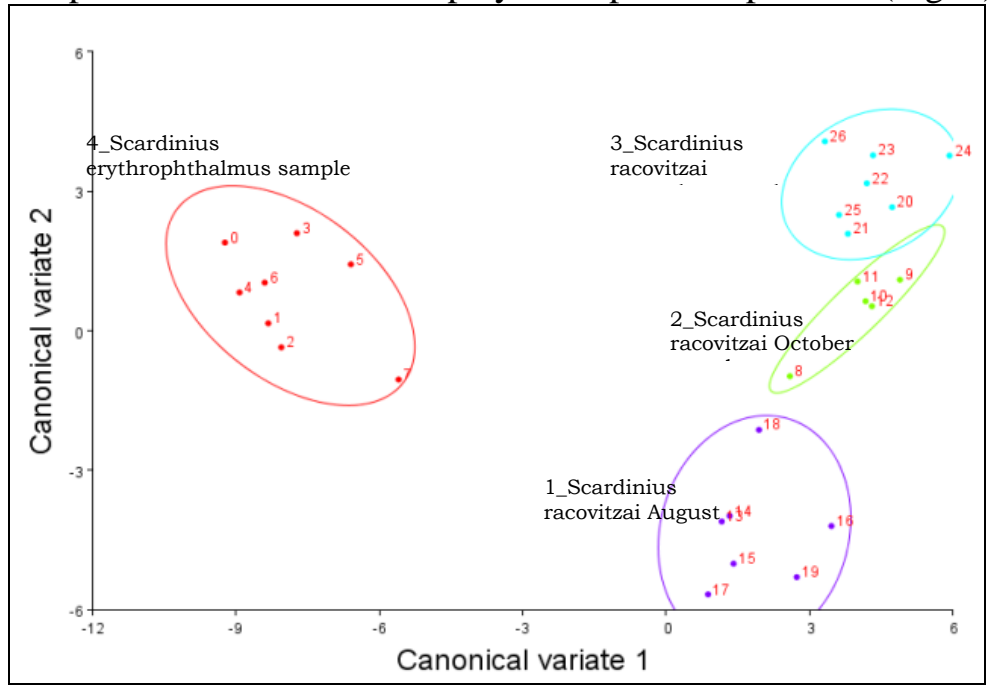

Figure 8: The scatter plot of the CV scores with equal frequency ellipses $(P=0.9)$ that group the coordinates by sampling stage. 
CVA generated as a result the matrices of farthest Mahalanobis distances between group number four (S. erythrophthalmus) and the other three (representing the observations on Peţea lake fish) (Tab. 9). P-values from permutation tests (10.000 permutation rounds) for Mahalanobis distances among groups are statistically significant $(\mathrm{P}<0.05)$.

The analysis of the geometry of individuals from the two species generated results in accordance with the morphometric discriminant analysis, yet a larger number of observations are needed for greater accuracy of results.

Table 9: Matrix with Mahalanobis distances among groups.

\begin{tabular}{|c|c|}
\hline Sample & $\begin{array}{c}\text { Sample } \\
\text { no. 4 }\end{array}$ \\
\hline $\begin{array}{c}\text { Sample } \\
\text { no. 1 }\end{array}$ & 12.2975 \\
\hline $\begin{array}{c}\text { Sample } \\
\text { no. 3 }\end{array}$ & 12.4924 \\
\hline $\begin{array}{c}\text { Sample } \\
\text { no. 2 }\end{array}$ & 11.0096 \\
\hline
\end{tabular}

\section{CONCLUSIONS}

Following the deterioration of the thermal ecosystem, one proposed the morphological variation in $S$. racovitzai and a detailed testing of morphometric features of individuals extracted from present thermal rudd population (Scardinius racovitzai) sampling during 2013, by comparing it to different references and also to its congener S. erythrophthalmus.

This study completes the data regarding the morphometric characters in S. racovitzai.

The statistical analysis of morphological characteristics of $S$. racovitzai revealed slightly decreased ranges of them when compared to other references. This can be linked to fish phenotypic plasticity in relation with thermal environments, but there are also several other factors that could influence their physiological and behavioural responses: drastic evolution of abiotic factors from the last years during first stages of fish development, availability/abundance of food resources, etc. That is why a detailed study of scale morphometry as a measure of habitat condition is needed to in order to expand on the conclusions regarding the fish plasticity findings.

The hierarchical clustering complete linkage analysis revealed the similarities between data resulting from this study and available data from literature regarding $S$. racovitzai morphology. The dissimilarity with its congener, S. erythrophtalmus is also evidenced by graphical dendrogram and the farthest distance between clusters of two species.

The PCA analysis of morphometric data in S. racovitzaiexamined the patterns in the relations among observations and identified the contribution of several body features on the overall variability of fish such as body height, caudal peduncle height and length, fins length, head and mouth length, preanal, predorsal, preventral and preorbital distances. The large number of variables with impact on this variability is connected to sample size.

The geometric and morphometric analyses revealed shape variations and statistically significant differences between the populations of thermal rudd and S. erythrophthalmus. A total number of six morphological characteristics are the most useful for discerning between the species (head features, caudal peduncle and pectoral and ventral fins lengths).

Despite a clear separation of specified groups in the morphospace of multivariate analysis, applying molecular techniques is necessary as the modern technique for distinction between species or ecotypes. 


\section{ACKNOWLEDGEMENTS}

The results from this study are a part of the project regarding the captive breeding and ex situ maintaining of populations of Scardinius racovitzai and Melanopsis parreyssii funded by the Mohamed Bin Zayed Species Conservation Fund and the authors wish to thank the Fund for supporting the researches.

The authors also wish to thank to Mr. Telcean I., for his scientific suggestions and the personnel of the Aquarium Department of Museum Complex of Natural Sciences Galaţi for their contribution in the husbandry of the experimental stock.

\section{REFERENCES}

1. Bănărescu P., 1964 - Pisces - Osteichthyes, Fauna Republicii Populare Române, XIII, Edit. Academiei Republicii Populare România, București, 962. (in Romanian)

2. Bănărescu P., 2002 - Species and subspecies of fish fauna and lampreys endemic or almost endemic to the drainage area of the river, TISCIA monograph series, 6, 167-172.

3. Berinkey L., 1960 - On the systematical position of Scardinius racovitzai, Müller, 1958, Vertebrata Hungarica, II, 2, 143-152.

4. Bohlen J., Freyhof J. and Nolte A., 2008 - Sex ratio and body size in Cobitis elongatoides and Sabanejewia balcanica (Cypriniformes, Cobitidae) from a thermal spring, Folia Zoologica, 57, 1-2, 191-197.

5. Crăciun N., 1997 - Ethological researches on Scardinius racovitzai from the Thermal Lake 1 Mai (Oradea), Studii şi Cercetări, Seria Biologie, Universitatea Bacău, 2, 79-88.

6. Danciu V. M., 2007 - Aspecte cu privire la problematica legată de întreţinerea ecologică a rezervaţiei naturale „Pârâul Peţea”, Nymphaea, Oradea, XXXIV, 123-142. (in Romanian)

7. Danciu V. M., 2006 - Monitoring parameters related to the water in lake Ochiul Mare of the natural reservation Peţa Rivulet (Bihor County), Studii şi Comunicări, Bacău, 21, 536-543.

8. $\quad$ Engelman L., 2005 - Discriminant analysis, Systat 11, Statistics manual, I, 301-359.

9. Freyhof J. and Kottelat M., 2008 - Scardinius racovitzai, The IUCN Red List of Threatened Species, Version 2014.3. http://www.iucnredlist.org/details/19948/0, 22 December 2014.

10. Fehér Z., 2013 - Melanopsis parreyssii, The IUCN Red List of Threatened Species, Version 2014.3, http://www.iucnredlist.org/details/155737/0, downloaded on 22 December 2014.

11. Ionaşcu A., 2011 - Monitoringul ecologic şi analiza comportamentului unor specii de peşti ameninţate cu dispariţia din fauna României, Teză de doctorat, Universitatea din Bucureşti. (in Romanian)

12. Klingenberg C. P., 2011 - MorphoJ: an integrated software package for geometric morphometrics, Molecular ecology resources, 11, 353-357.

13. Marossy A., 1976 - Factori antropici ce au modificat echilibrul ecologic al Rezervaţiei Naturale „Pârâul Pețea”, Nymphaea, IV, 261-272. (in Romanian)

14. Maitland P. S. and Morgan N. C., 2002 - Conservation management of freshwater habitats lakes, rivers and wetlands, Kluwer Academic Publishers, Norwell, Massachusetts, USA.

15. Müller G. J., 1958 - Scardinius racovitzai n. sp. (Pisces, Cyprinidae), eine reliktäre Rotfeder aus Westrumänien, Senckenbergiana biologica, Band 39, 3/4, 165. (in German)

16. Paina M. I., 1978 - Câteva consideraţii asupra factorilor abiotici în rezervaţia naturală de la Băile 1 Mai. Temperatura, Nymphaea, 6, 645-672. (in Romanian)

17. Polly D. P., 2012 - A basic geometric morphometric analysis, G 562 Geometrics Morphometrics, USA.

18. Prein M., Hulata G. and Pauly D., 1993 - Multivariate methods in aquaculture research: case study of tilapias in experimental and commercial systems, ICLARM Studies Review, 20, 221.

19. Sîrbu I., Gagiu A. A. and Benedek M., 2013 - On the brink of extinction: fate of the Peţea thermal lake (Romania) and its endemic species, Tentacle, 21.

20. Stenson H. and Wilkinson L., 2005 - Factor analysis, Systat 11. Statistics manual, I, 359-399. 
21. Telcean C. I. and Cupşa D., 2013 - The drastic decline of fish fauna in the thermal lake of "Băile 1 Mai" (Băile Episcopale, Bihor County, Romania), Pisces Hungarici, 7, 141-142.

22. Wilkinson L., 2005 - Cluster analysis, Systat 11. Statistics manual, I, 68-90.

23. Kottelat M. and Freyhof J., 2007, www.fishbase.org.

24. The transport of live fish, www.fao.org/.

25. IUCN/SSC, 1995 - Guidelines For Re-Introductions, Prepared by the SSC Re-introduction Specialist Group Approved by the 41st Meeting of the IUCN Council, Gland Switzerland, http://www.iucnsscrsg.org/.

26. IUCN, 2002 - Technical Guidelines on the Management of Ex-situ populations for Conservation Approved at the 14th Meeting of the Programme Committee of Council, Gland Switzerland.

27. http://fishbase.pl/2011/10/rosioarei-termale-scardinius-racovitzai/. 